\title{
Virchow's node
}

\section{Deepak Sundriyal, ${ }^{1}$ Naveen Kumar, ${ }^{2}$ Sumit Kumar Dubey, ${ }^{2}$ Meenu Walia ${ }^{1}$}

1 Department of Medical Oncology, Dharamshila Hospital, New Delhi, India ${ }^{2}$ Department of Medicine, PGIMER \& Dr Ram Manohar Lohia Hospital, New Delhi, India

\section{Correspondence to}

Dr Naveen Kumar, docnaveen2605@yahoo.co.in

\section{DESCRIPTION}

A 57-year-old man presented to us with epigastric pain, decreased appetite, weight loss $(8 \mathrm{~kg})$ for 2 months prior to presentation. He noted a lump on the left side of the neck for 15 days. He was a chronic smoker, smoking two packs of bidi per day for about 20 years. On examination, he had a $3.5 \times 4 \mathrm{~cm}$, firm, non-tender lump in the left supraclavicular region between the two heads of the sternocleidomastoid muscle, that is, Virchow's node (figure 1). Systemic examination was normal. An upper gastrointestinal (GI) endoscopy revealed an ulceroproliferative growth in the antrum (figure 2). A histopathological examination following the biopsy was consistent with adenocarcinoma.

Virchow's node lies near to the junction of the thoracic duct and the left subclavian vein, where the lymph from most of the body drains into the systemic circulation. ${ }^{1}$ Tumour embolisation of the GI cancers via the thoracic duct usually leads to the enlargement of left supraclavicular node. The latter is called Troisier's sign and can be the first clue to a GI malignancy. For the same reason, they are also called sentinel or signal nodes. Stomach cancer primarily presenting with Troisier's sign without any other symptoms is very uncommon. It is important to know that metastasis to the supraclavicular lymph node indicates stage 4 disease. Although Virchow's node or the Troisier's node is typically enlarged in gastric cancer, it can also be seen in lymphoma, breast, oesophageal, pelvic and

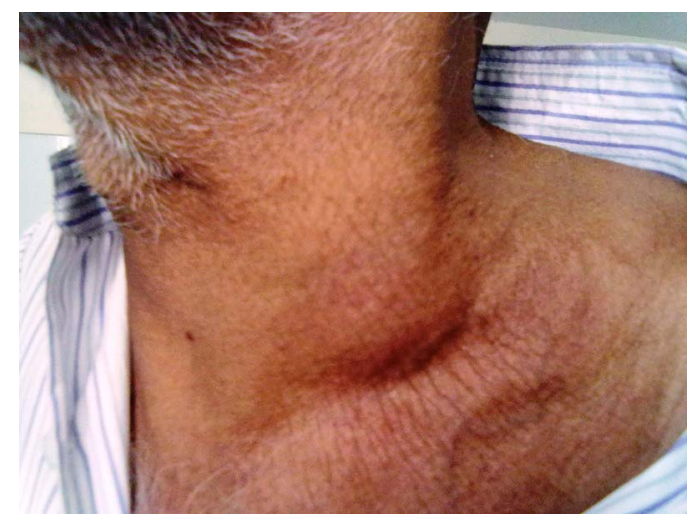

Figure 1 Enlarged node in the left supra-clavicular region.

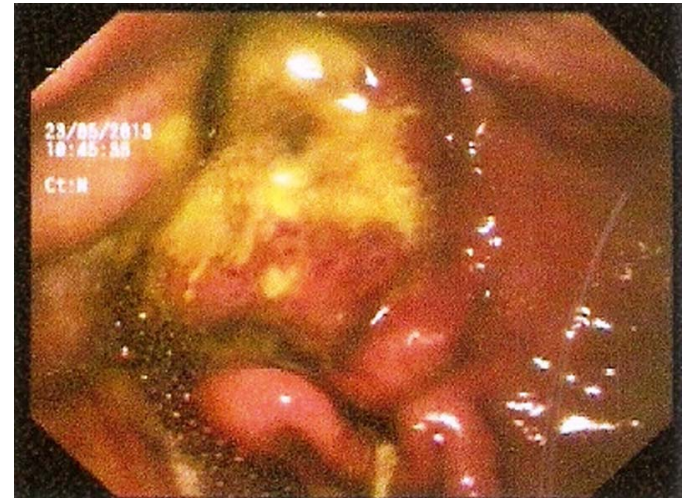

Figure 2 Upper gastrointestinal endoscopy showing ulceroproliferative growth in the antrum.

testicular cancers. ${ }^{2}$ Due to the poor performance status, we referred our patient for palliative therapy.

\section{Learning points}

- Due to superficial location and hence easy examination, Virchow's node enlargement is an important clue for the gastrointestinal (GI) malignancy.

- It is a sign of advanced disease.

- Virchow's node can also enlarge in non-GI malignancies like lymphoma, breast, oesophageal, pelvic and testicular cancers.

Contributors DS and NK were involved in patient management, concept of paper, data acquisition, drafting the article, revision and final approval. SKD was involved in patient management, concept of paper, data acquisition, revision and final approval. MW involved in patient management, concept of paper, drafting the article, revision, final approval.

Competing interests None.

Patient consent Obtained.

Provenance and peer review Not commissioned; externally pee reviewed.

\section{REFERENCES}

1 Baumgart DC, Fischer A. Virchow's node. Lancet 2007;370:1568.

2 Siosaki MD, Souza AT. Virchow's node. N Engl J Med 2013;368:6.
To cite: Sundriyal $\mathrm{D}$ Kumar N, Dubey SK, et al. BMJ Case Rep Published online: [please include Day Month Yearl doi:10.1136/ bcr-2013-200749 


\section{Images in...}

Copyright 2013 BMJ Publishing Group. All rights reserved. For permission to reuse any of this content visit http://group.bmj.com/group/rights-licensing/permissions.

BMJ Case Report Fellows may re-use this article for personal use and teaching without any further permission.

Become a Fellow of BMJ Case Reports today and you can:

- Submit as many cases as you like

- Enjoy fast sympathetic peer review and rapid publication of accepted articles

- Access all the published articles

- Re-use any of the published material for personal use and teaching without further permission

For information on Institutional Fellowships contact consortiasales@bmjgroup.com

Visit casereports.bmj.com for more articles like this and to become a Fellow 